\title{
Quercetin Derivatives from Siegesbeckia glabrescens Inhibit the Expression of COX-2 Through the Suppression of NF-кB Activation in Microglia
}

\author{
Hyo Jin Lim ${ }^{1}$, Hua Li ${ }^{1}$, Jae Yeon Kim ${ }^{1}$ and Jae-Ha Ryu ${ }^{1, *}$ \\ ${ }^{1}$ College of Pharmacy, Sookmyung Women's University, Seoul 140-742, Republic of Korea
}

\begin{abstract}
The activation of microglia induces the overproduction of inflammatory mediators that are responsible for the neurodegenerative disorders including Alzheimer's disease and Parkinson's disease. The large amounts of prostaglandin $E_{2}\left(P G E_{2}\right)$ produced by inducible cyclooxygenase (COX-2) is one of the main inflammatory mediators that can contribute to neurodegeneration. The inhibition of COX-2 thus may provide therapeutic strategy for the treatment of neurodegenerative diseases. From the activityguided purification of EtOAc soluble fraction of Siegesbeckia glabrescens, four compounds were isolated as inhibitors of PGE ${ }_{2}$ production in LPS-activated microglia. Their structures were determined as 3, 4'-dimethylquercetin (1), 3, 7-dimethylquercetin (2), 3-methylquercetin (3) and 3, 7, 4'-trimethylquercetin (4) by the mass and NMR spectral data analysis. The compounds 1-4 showed dose-dependent inhibition of $\mathrm{PGE}_{2}$ production in LPS-activated microglia with their $\mathrm{IC}_{50}$ values of $7.1,4.9,4.4,12.4 \mu \mathrm{M}$ respectively. They reduced the expression of protein and mRNA of COX-2 through the inhibition of I- $\kappa \mathrm{B} \alpha$ degradation and NF- $\mathrm{B}$ activity that were correlated with the inactivation of p38 and ERK. Therefore the active compounds from Siegesbeckia glabrescens may have therapeutic effects on neuro-inflammatory diseases through the inhibition of overproduction of $\mathrm{PGE}_{2}$ and suppression of COX-2 overexpression.
\end{abstract}

Key Words: Siegesbeckia glabrescens, Quercetin, Cyclooxygenase, Nuclear factor kappa B, Microglia

\section{INTRODUCTION}

Microglia, the immune regulatory and inflammatory cells play a role in host defense and tissue repair in the central nervous system (CNS) (Perry and Gordon, 1988). They can be activated in response to a variety of neurodegenerative and neuro-inflammatory conditions, resulting in the amplication of inflammation and the mediation of cellular degeneration (Gonzalez-Scarano and Baltuch, 1999). The activation of microglia leads to the induction of inflammatory enzymes such as inducible nitric oxide synthase (iNOS) and cyclooxygenase (COX-2), as well as the release of proinflammatory cytokines including TNF- $\alpha$, IL-1 $\beta$, IL-6 (Allen and Tresini, 2000; Klein and Ackerman, 2003). The inflammatory mediators produced by activated microglia are responsible for the neurodegenerative disorders, including Alzheimer's disease and Parkinson's disease (McGeer and McGeer, 1995; Block et al., 2007).

Prostaglandins (PGs) are lipid mediators that regulate several physiologic and pathophysiologic processes in both homeostatic and inflammatory conditions (Harris et al., 2002).
PGs can be produced through the successive conversion of arachidonic acid by major isoenzymes, COX-1 and COX2. COX-1 is a constitutive form in most tissues responsible for cellular homeostasis, while COX-2 is an inducible form. COX-2 can be induced by cytokines, hormones, mitogens and inflammatory stimuli in inflammatory cells such as macrophages, microglia, dendritic cells (Brock et al., 1999). COX has been observed in mammalian brain and the COX-2 plays a significant role in the production of inflammatory PGs (Peri et al., 1995). Under normal condition, COX-2 can be expressed and contributes to fundamental brain functions, such as synaptic activity, memory consolidation, and functional hyperemia (Minghetti, 2004). The overproduction of $\mathrm{PGE}_{2}$ by COX-2 plays a central role in brain diseases including ischemic injury and several neurodegenerative diseases. Under inflammatory conditions, therefore, COX-2 has to be under tight control for the blocking the detrimental effects of $\mathrm{PGE}_{2}$. The inhibition of COX-2 attenuates the levels of inflammatory mediators including TNF- $\alpha$, IL-1 $\beta$ and iNOS in injured brain tissue (Kyrkanides et al., 2002). Thus, the modulation of COX-2 expression can www.biomolther.org

Open Access DOI: 10.4062/biomolther.2011.19.1.027

pISSN: 1976-9148 elSSN: 2005-4483

Copyright $\odot 2011$ The Korean Society of Applied Pharmacology
Received Oct 11, 2010 Revised Nov 9, 2010 Accepted Nov 9, 2010

\footnotetext{
*Corresponding Author

E-mail: ryuha@sookmyung.ac.kr

Tel: +82-2-710-9568, Fax: +82-2-714-0745
} 
be a good strategy for the management of CNS inflammation and related diseases.

We have screened anti-inflammatory activity of plant extracts which has been used as folk medicine. We have reported sesquiterpenes (Yoon et al., 2008), lignans (Ryu et al., 2002) and flavonoids (Lee et al., 2005) that can inhibit the expression of iNOS and COX-2 in activated microglia. Here, we report the identification of four quercetin derivatives from Siegesbeckia glabrescens and their inhibitory activities of $\mathrm{PGE}_{2}$ production, COX-2 expression and NF- $\mathrm{KB}$ activation.

\section{MATERIALS AND METHODS}

\section{Plant materials}

The whole plant of Siegesbeckia glabrescens was collected from Wan-Do, Jeolla-Namdo, Korea in November 2005. The obtained material $(2.7 \mathrm{~kg})$ was air-dried and extracted three times with 2 I of methanol at RT for $24 \mathrm{~h}$. The extracted solution was filtered and evaporated in vacuo, the residue (190 g) was successively partitioned with $n$-hexane, EtOAc, $\mathrm{CHCl}_{3}$ and $\mathrm{BuOH}$. The activity-guided chromatography was followed for the purification of bioactive compounds as reported previously (Kim et al., 2008). Four flavonoids were isolated from the EtOAc soluble fraction by repeated column chromatography on silica gel using gradient elution with $n$-hexane-acetone, $n$-hexane-EtOAc and $\mathrm{CHCl}_{3}-\mathrm{MeOH}$. For further purification, RP-C18 column (LiChroprep RP-C18, 40-63 $\mu \mathrm{m}$, Merck) was used with a gradient elution of $\mathrm{MeOH} /$ water $(50 \% \rightarrow 100 \%)$. The purity of compounds was confirmed by reverse phase HPLC analysis (Inertsil ODS-2, 4.6×100 mm; 80\% MeOH, 1.0 $\mathrm{ml} / \mathrm{min}$; UV $254 \mathrm{~nm}$ ). The structure of compounds was identified by the analysis of IR, Mass and NMR spectroscopic data analysis.

\section{Cell culture}

Murine microglial cell line (BV-2) was kindly provided by Prof. Hee-Sun Kim at Ewha Womans University, Korea. Cells were cultured in DMEM containing $10 \%$ fetal bovine serum, 2 $\mathrm{mM}$ glutamine, $1 \mathrm{mM}$ pyruvate, penicillin $(100 \mathrm{U} / \mathrm{ml})$ and streptomycin $(10 \mu \mathrm{g} / \mathrm{ml})$. BV-2 cells were seeded at $5 \times 10^{5}$ cells $/ \mathrm{ml}$ in 48 well plates and were activated by incubation in medium containing LPS $(0.1 \mu \mathrm{g} / \mathrm{ml}$, Escherichia coli, 0127:B8, Sigma, St. Louis, MO) and various concentrations of test compounds dissolved in DMSO (0.1\% final concentration in media). The supernatant was collected as a source of secreted $\mathrm{PGE}_{2}$.

\section{Measurement of prostaglandin $\mathrm{E}_{2}$}

$\mathrm{PGE}_{2}$ enzyme immunometric assay (EIA) was performed according to Pradelles (Pradelles et al., 1985) with the minor modification (Cayman Chemical, Ann Arbor, MI). In brief, $50 \mu \mathrm{l}$ of supernatant from the culture medium and $50 \mu \mathrm{PGE}_{2}$ EIA tracer were put into the $\mathrm{PGE}_{2}$ EIA 96-well plate and the plate were incubated for $18 \mathrm{~h}$. Wells were washed with $10 \mathrm{mM}$ phosphate buffer ( $\mathrm{pH} 7.4$ ) containing $0.05 \%$ Tween 20 , followed by the addition of $200 \mu \mathrm{l}$ of Ellman's reagent and incubation at RT. Following the developing step, absorbance in each well at $405 \mathrm{~nm}$ was read using a microplate spectrometer. A standard curve was developed simultaneously with standard ranging from 0.06 to $6 \mathrm{pg} / \mu \mathrm{PGE}_{2}$.

\section{Western blot analysis}

The cells were rinsed with phosphate buffered saline and lysed by boiling with lysis buffer ( $1 \%$ SDS, $1.0 \mathrm{mM}$ sod. vanadate, $10 \mathrm{mM}$ Tris, $\mathrm{pH}$ 7.4) for 5 min. Twenty $\mu \mathrm{g}$ protein of cell lysates was applied on SDS-polyacrylamide gels and transferred to PVDF membrane by the standard method. The membrane was probed with antibodies against COX-2 (Cayman Chemical Company, Ann Arbor, MI), $\beta$-actin (Sigma Chemical Co., St. Louis, MO), l-кB $\alpha$ and p65 (Santa Cruz Biotechnologies Inc. Santa Cruz, CA). Antibodies against ERK1/2, phospho-ERK1/2, p38, phospho-p38, JNK, and phospho-JNK were from Cell Signaling Technology (Beverly, MA). The blot was visualized using an enhanced chemiluminescence $(E C L)$ detection kit (Amersham bioscience, Piscataway, NJ) according to the manufacturer's instruction.

\section{Reverse transcription and polymerase chain reaction (RT-PCR)}

BV-2 cells were pre-treated with and without plant samples for $30 \mathrm{~min}$ prior to LPS $(0.1 \mu \mathrm{g} / \mathrm{ml})$ for $4 \mathrm{~h}$. The whole RNA was isolated with TRIzol ${ }^{\circledR}$ reagent (Invitrogen, Carlsbad, CA). Each RNA extract $(2 \mu \mathrm{g})$ was reverse-transcribed into cDNA using superscript II reverse transcriptase (Invitrogen, Carlsbad, CA). PCR was performed in $25 \mu$ l of a solution containing Go Taq $^{\text {TM }}$ DNA polymerase (Promega, Madison, WI), COX-2 primer, $\alpha$-actin primer, and RT products. The sense and antisense primers for COX-2 were 5'-CCAGATGCTATCTTTGGGGAGAC-3' and 5'-CTTGCATTGATGGTGGCTG- 3', respectively. The sense and antisense primers for $\alpha$-actin were 5'-TGTGATGGTGGGAATGGGTCAG-3' and 5'-TTTGATGTCACGCACGATTTCC-3', respectively. After preincubation for $5 \mathrm{~min}$ at $94^{\circ} \mathrm{C}, 30$ cycles of amplification $\left(94^{\circ} \mathrm{C}\right.$ for $30 \mathrm{~s}, 30^{\circ} \mathrm{C}$ for $30 \mathrm{~s}$ and $72^{\circ} \mathrm{C}$ for $1 \mathrm{~min}$ ) were performed for COX-2. After preincubation for $3 \mathrm{~min}$ at $94^{\circ} \mathrm{C}, 26$ cycles of amplification $\left(94^{\circ} \mathrm{C}\right.$ for $1 \mathrm{~min}, 64^{\circ} \mathrm{C}$ for $1 \mathrm{~min}$ and $72^{\circ} \mathrm{C}$ for $1 \mathrm{~min}$ ) were performed for $\alpha$-actin. The level of $\alpha$-actin was used for an internal control. Each PCR reaction was analyzed by $2 \%$ agarose gel electrophoresis in Tris acetate-EDTA buffer and stained with ethidium bromide.

\section{NF-kB luciferase assay}

BV-2 cells were seeded at $1 \times 10^{5}$ cells $/ \mathrm{ml}$ in 48 well plates. After incubating at $37^{\circ} \mathrm{C}$ for $24 \mathrm{~h}$, the cells were transfected with $0.5 \mu \mathrm{g}$ of NF- $\mathrm{kB}$ luciferase reporter plasmid and $0.3 \mu \mathrm{g}$ of $\beta$-galactosidase plasmid in DMEM medium without FBS using SuperFect reagent according to the manufacturer's protocol (Qiagen, Valencia, CA). The cells were incubated for $3 \mathrm{~h}$, and then fresh $10 \%$ FBS DMEM medium was added. After $18 \mathrm{~h}$, the cells were preincubated with or without samples before being activated with LPS for $6 \mathrm{~h}$. The luciferase activity was determined using the luciferase assay system (Promega, Madison, WI) with a microplate luminometer (Wallac Victor3 ${ }^{\mathrm{TM}} 1420$ Multi Lable Counter, Perkin Elmer). The $\beta$-galactosidase activity was determined as described previously (Ye et al., 1994). The results are expressed as relative NF- $\mathrm{KB}$ activity compared with controls after normalizing for $\beta$-galactosidase activity.

\section{Electrophoretic mobility shift assay}

BV-2 cells were seeded at $1.0 \times 10^{6}$ cells $/ \mathrm{ml}$ in $60 \mathrm{~mm}$ dish for $24 \mathrm{~h}$ and were treated with and without samples and LPS $(0.1 \mu \mathrm{g} / \mathrm{ml})$ for $15 \mathrm{~min}$. The cells were rinsed with phosphate buffered saline and lysed with $10 \mathrm{mM}$ HEPES-KOH, $10 \mathrm{mM}$ 
$\mathrm{KCl}, 1.5 \mathrm{mM} \mathrm{MgCl}, 0.5 \mathrm{mM}$ DTT, $0.5 \mathrm{mM}$ PMSF, $0.1 \mathrm{mM}$ EDTA, $0.2 \mathrm{mM} \mathrm{NaF}$ and $0.2 \mathrm{mM}$ sod. orthovanadate $(\mathrm{pH} 7.9)$ for $15 \mathrm{~min}$. Nuclear protein was extracted in $50 \mathrm{mM}$ HEPES$\mathrm{KOH}, 50 \mathrm{mM} \mathrm{KCl}, 1.5 \mathrm{mM} \mathrm{MgCl}$, $300 \mathrm{mM} \mathrm{NaCl}, 0.5 \mathrm{mM}$ DTT, $0.5 \mathrm{mM}$ PMSF, $0.1 \mathrm{mM}$ EDTA, $0.2 \mathrm{mM} \mathrm{NaF}, 0.2 \mathrm{mM}$ sod. orthovanadate and $25 \%$ glycerol $(\mathrm{pH} 7.9)$ on ice for $30 \mathrm{~min}$. After cells were centrifuged for $20 \mathrm{~min}$ at $14,000 \times \mathrm{g}$, supernatants with nuclear proteins were transferred into pre-cooled tube and protein concentrations were determined. Equal amount $(15 \mu \mathrm{g})$ of nuclear protein from the cells were reacted with ${ }^{32} \mathrm{P}$-labeled oligonucleotide specific to NF- $\mathrm{KB}$ in a binding buffer (10 mM HEPES-KOH, $50 \mathrm{mM} \mathrm{KCl,} 2.5 \mathrm{mM} \mathrm{MgCl}_{2}, 10 \mathrm{mM}$ DTT, $1 \mu \mathrm{g} / \mathrm{ml}$ poly (dl-dC), and $5 \%$ glycerol, $\mathrm{pH} 7.4$ ) for $10 \mathrm{~min}$ on ice. The complexes between oligonucleotide and nuclear protein were resolved on non-denaturing $6 \%$ polyacrylamide gel by electrophoresis. The gels were dried and exposed to X-ray film.

\section{Statistics}

The results were expressed as mean \pm S.D. of three experiments, and statistical analysis was performed by the Student's t-test, and a $p$-value of $<0.05$ was considered to indicate a significant difference.

\section{RESULTS AND DISCUSSION}

Microglia are immune cells found in CNS that can be activated by the exposure of lipopolysaccharide (LPS), interferon$\gamma$ or $\beta$-amyloid (Zielasek and Hartung, 1996; Lehnardt et al., 2003). Activated microglia release various kinds of neurotoxic factors, including $\mathrm{PGE}_{2}$, nitric oxide (NO) and pro-inflammatory cytokines that can result in brain injury and neurodegenerative diseases including Alzheimer's diseases, Parkinson's disesase and traumatic multiple sclerosis. Therefore, the regulation of microglial activation might lead to the useful strategies for the treatment of neurodegenerative disorders.

As a part of our on-going screening program to evaluate the anti-inflammatory potentials of plant-derived compounds (Ryu et al., 2002; Lee et al., 2005; Yoon et al., 2008), we investigated the inhibitors of $\mathrm{PGE}_{2}$ synthesis in LPS-activated microglia. Siegesbeckia glabrescens (Compositae), well known as 'Hi-Chum' has been used as traditional medicine for the treatment of rheumatoid arthritis, asthma, paralysis and allergic disorders. Recently, it has been reported that the extracts of $S$. glabrescens exhibit antioxidant, antiallergic, antihypertension, antitumor, and anti-inflammatory activities (Kim et al., 2001; Jun et al., 2006; Kim et al., 2008).

In order to screen the biological activity of plant-derived principles, we used the LPS-activated microglial system. The stimulation of microglia is a useful model for the activity screening of neuroprotective agents by monitoring inflammatory mediators. The activation of microglia has been considered to be related with various pathological process during neuropathological changes of central nervous system. The treatment of LPS $(0.1 \mu \mathrm{g} / \mathrm{ml}, 20 \mathrm{~h})$ into microglial cell, BV-2 cells, increased the production of $\mathrm{PGE}_{2}$ up to $5 \mathrm{pg} / \mathrm{well}$ as a main inflammatory mediator produced by COX-2. From the activity-guided purification process using EtOAc soluble fraction of Siegesbeckia glabrescens, we isolated four inhibitors (1-4) of $\mathrm{PGE}_{2}$ production in activated BV-2 cells (Fig. 1). Their structures were elucidated as 3,4'-dimethylquercetin (1),<smiles>[R20]Oc1cc(O)c2c(=O)c(O[R2])c(-c3ccc([R6])c(O)c3)oc2c1</smiles>

$$
\begin{aligned}
& \text { 1: } \mathrm{R}_{1}=\mathrm{CH}_{3}, \mathrm{R}_{2}=\mathrm{H}, \mathrm{R}_{3}=\mathrm{CH}_{3} \\
& \text { 2: } \mathrm{R}_{1}=\mathrm{CH}_{3}, \mathrm{R}_{2}=\mathrm{CH}_{3}, \mathrm{R}_{3}=\mathrm{H} \\
& \text { 3: } \mathrm{R}_{1}=\mathrm{CH}_{3}, \mathrm{R}_{2}=\mathrm{H}, \mathrm{R}_{3}=\mathrm{H} \\
& \text { 4: } \mathrm{R}_{1}=\mathrm{CH}_{3}, \mathrm{R}_{2}=\mathrm{CH}_{3}, \mathrm{R}_{3}=\mathrm{CH}_{3}
\end{aligned}
$$

Fig. 1. Chemical structures of compounds 1-4 from Siegesbeckia glabrescens.

3,7-dimethylquercetin (2), 3-methylquercetin (3) and 3,7,4'-trimethylquercetin (4) by spectroscopic analysis and confirmed by the comparison of the reported data (Ramachandran Nair et al., 1978; Barberá et al., 1986; Wang et al., 1989).

To evaluate the anti-inflammatory potential of compounds, we determined the $\mathrm{PGE}_{2}$ level in LPS-activated microglia. Cells were allowed to adhere for $2 \mathrm{~h}$, in the presence of aspirin $(500 \mu \mathrm{M})$ to inactivate endogenous COX-1. And then, cells were washed three times with fresh media and incubated with LPS $(0.1 \mu \mathrm{g} / \mathrm{ml})$ and test compounds for $20 \mathrm{~h}$. The amounts of $\mathrm{PGE}_{2}$ released into culture media were analyzed by $\mathrm{PGE}_{2}$ enzyme immunoassay kit. Compounds 1-4 inhibited $\mathrm{PGE}_{2}$ production in LPS-activated BV-2 microglia in a dose dependent manner. The $\mathrm{IC}_{50}$ values, the concentrations of compounds 1-4 responsible for the $50 \%$ inhibition of $\mathrm{PGE}_{2}$ production, were $7.1,4.9,4.4,12.4 \mu \mathrm{M}$, respectively (Fig. 1). The quercetin derivatives 2 and 3 were somewhat stronger inhibitors than 1 and 4 . The methylation of 4' position of ring $B$ reduced the inhibitory activity of $\mathrm{PGE}_{2}$ production. The activity of quercetin was the weakest among the tested derivatives with $\mathrm{IC}_{50}$ value of $32 \mu \mathrm{M}$ that was the relevant value of reported data (Chen et al., 2001). Cell viability was above $85 \%$ at the concentrations of $\mathrm{PGE}_{2}$ assay when assessed by MTT method. The inhibition of $\mathrm{PGE}_{2}$ production might come from either the inhibition of COX-2 enzyme activity or the suppression of COX-2 induction. In order to reveal the mechanism for the inhibition of $\mathrm{PGE}_{2}$ production, we analyzed the effects of compounds on the expression level of protein and mRNA of COX-2 in LPSactivated microglia. The cell lysate of vehicle treated cells did not show detectable COX-2 protein. The treatment of 1-4 (20 $\mu \mathrm{M})$ showed the significant decrease of the COX-2 protein expression by LPS-activated microglia (Fig. 2). The results of reverse transcription-polymerase chain reaction (RT-PCR) analysis also showed that compounds 1-3 $(20 \mu \mathrm{M})$ inhibited the expression of COX-2 mRNA in LPS-activated microglia (Fig. 3 ). The amounts of protein and mRNA expression were quantitated from the volume intensity of the bands corresponding to COX-2 and actin.

To elucidate the further mechanism of compounds for COX2 inhibition in microglia, we determined effects of compounds on the NF- $\mathrm{KB}$ activity and level of $\mathrm{I}-\kappa \mathrm{B} \alpha$ in LPS-activated microglia. NF- $\kappa B$ is an important transcription factor for proinflammatory mediators including iNOS and COX-2 induction (Kim et 


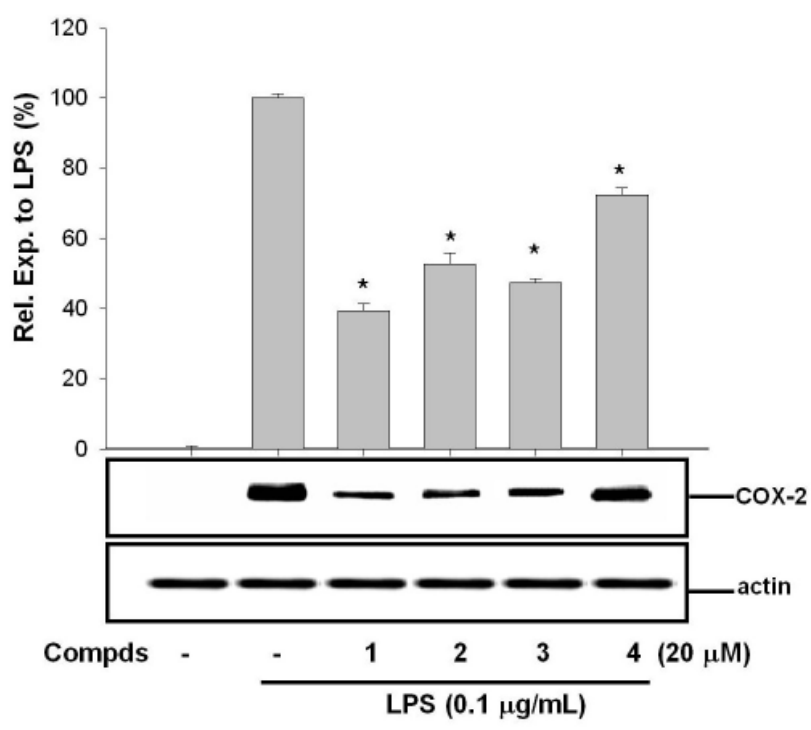

Fig. 2. Effects of 1-4 on the expression of COX-2 protein in LPSactivated BV-2 cells. Cells were treated with compounds $(20 \mu \mathrm{M})$ during LPS activation for $20 \mathrm{~h}$. The protein expressional level was determined by Western blotting. Values with asterisk represent significant $(p<0.05)$ differences of protein expression compared with LPS-media control. Values are expressed as the mean \pm S.D. of triplicate measurements.

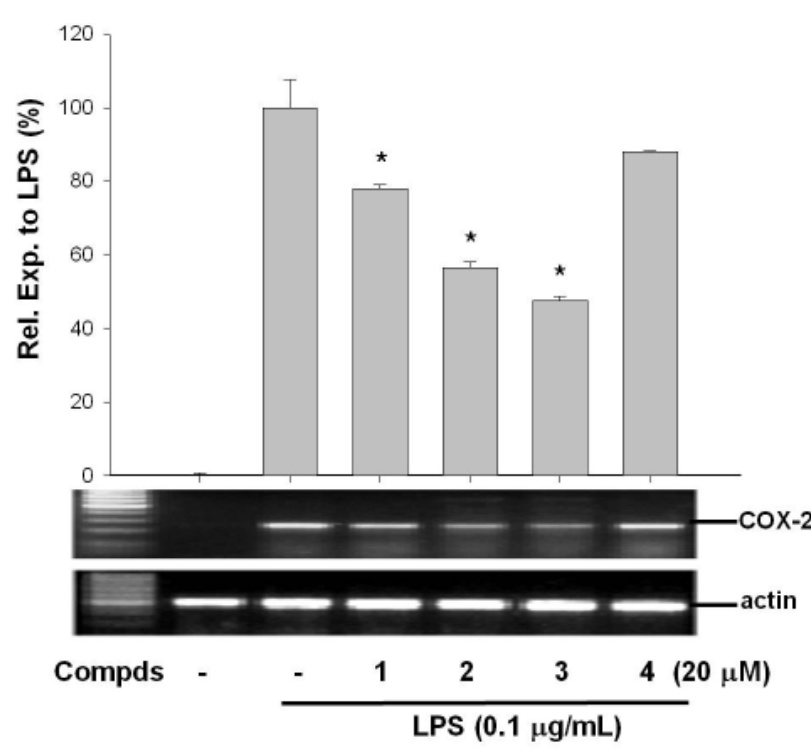

Fig. 3. Effects of 1-4 on the expression of COX-2 mRNA in LPSactivated BV-2 cells. Cells were pretreated with coompounds (20 $\mu \mathrm{M})$ for $30 \mathrm{~min}$ prior to LPS $(0.1 \mu \mathrm{g} / \mathrm{ml})$ treatment. After $4 \mathrm{~h}$ of LPS treatment, COX-2 mRNA levels were determined by RT-PCR based assays. Values with asterisk represent significant $(p<0.05)$ differences of mRNA expression compared with LPS-media control. Values are expressed as the mean \pm S.D. of triplicate measurements.

al., 1997). The NF-kB can be activated by the degradation of inhibitory- $\mathrm{B}(\mathrm{I}-\kappa \mathrm{B})$ through its phosphorylation (Lee et al., 2001). I-אB $\alpha$ was fully degraded by 30 min exposure of LPS

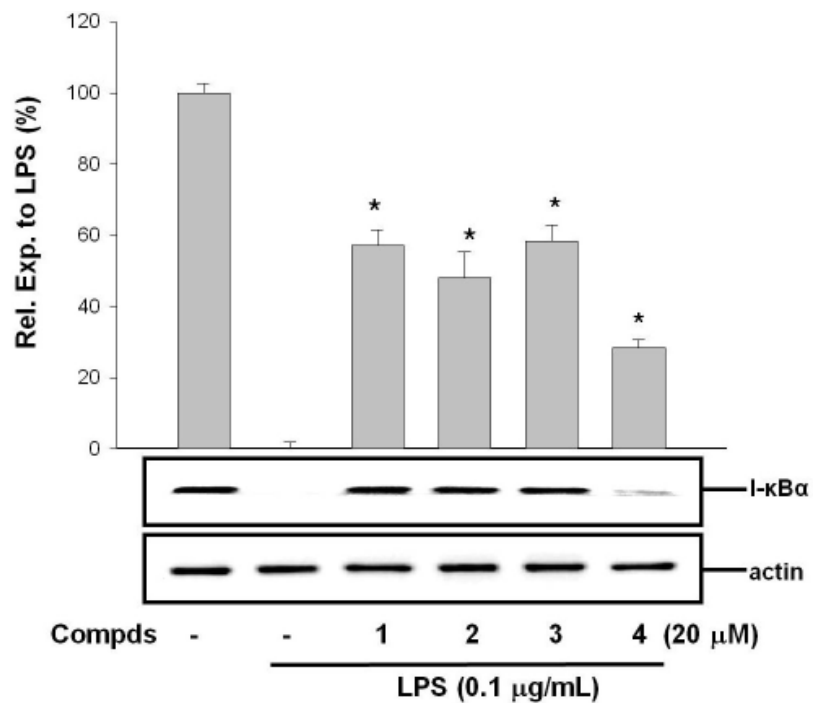

Fig. 4. Effect of compounds $1-4$ on $1-\kappa \mathrm{B} \alpha$ degradation in LPS-activated microglia. Cells were pretreated with compounds $(20 \mu \mathrm{M})$ for $30 \mathrm{~min}$ and incubated with LPS $(0.1 \mu \mathrm{g} / \mathrm{ml})$ for $30 \mathrm{~min}$. The protein levels of $\mathrm{I}-\mathrm{\kappa} \mathrm{B} \alpha$ were determined by Western blotting. Values with asterisk represent significant $(p<0.05)$ differences of $\mathrm{I}-\kappa \mathrm{B} \alpha$ level compared with LPS-media control. Values are expressed as the mean \pm S.D. of triplicate measurements.

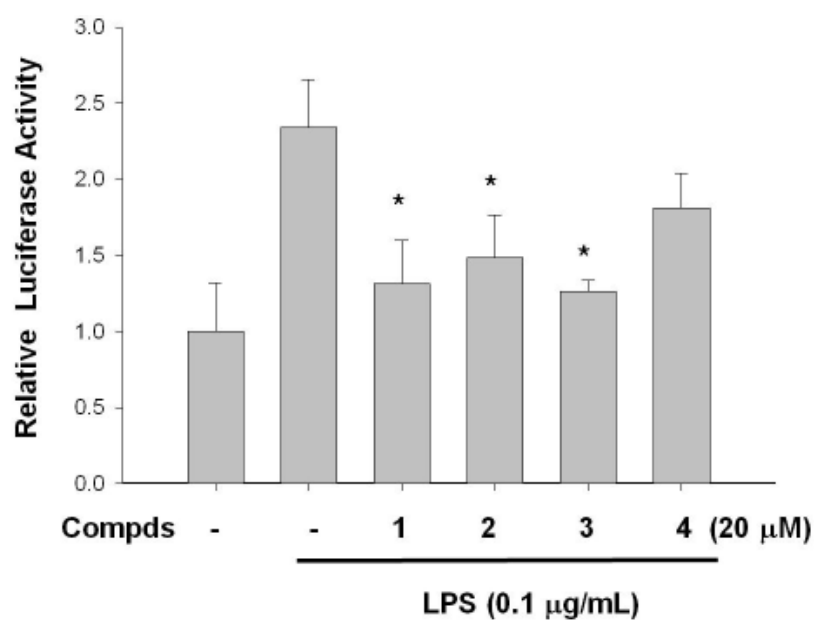

Fig. 5. Effect of compounds $1-4$ on NF- $\kappa B$ activation in LPSactivated BV-2 cells. Transfected BV-2 cells were pretreated with compounds $(20 \mu \mathrm{M})$ for $1 \mathrm{~h}$ and incubated with LPS $(0.1 \mu \mathrm{g} / \mathrm{ml})$ for $6 \mathrm{~h}$. The NF-KB activity was expressed as relative luciferase activity. Values with asterisk represent significant difference $(p<0.05)$ compared with LPS-media control. Values are expressed as the mean \pm S.D. of triplicate measurements.

$(0.1 \mu \mathrm{g} / \mathrm{ml})$ and followed by the recovery in microglia (data not shown) (Lee et al., 2005). As shown in Fig. 4, the degradation of $\mathrm{I}-\mathrm{\kappa B} \alpha$ was suppressed by the 30 min treatment of 1-4 (20 $\mu \mathrm{M})$ during the LPS activation of microglia. The NF- $\kappa B$ activity was measured by the luciferase reporter gene assay and electrophoretic mobility shift assay (EMSA). As shown in Fig. 5 , compounds 1-3 $(20 \mu \mathrm{M})$ suppressed the NF- $\kappa B$ reporter activity. Compounds 1-3 also suppressed LPS-induced NF-kB 
Lim et al. Quercetin Derivatives Inhibit NF- $\kappa$ B Activation
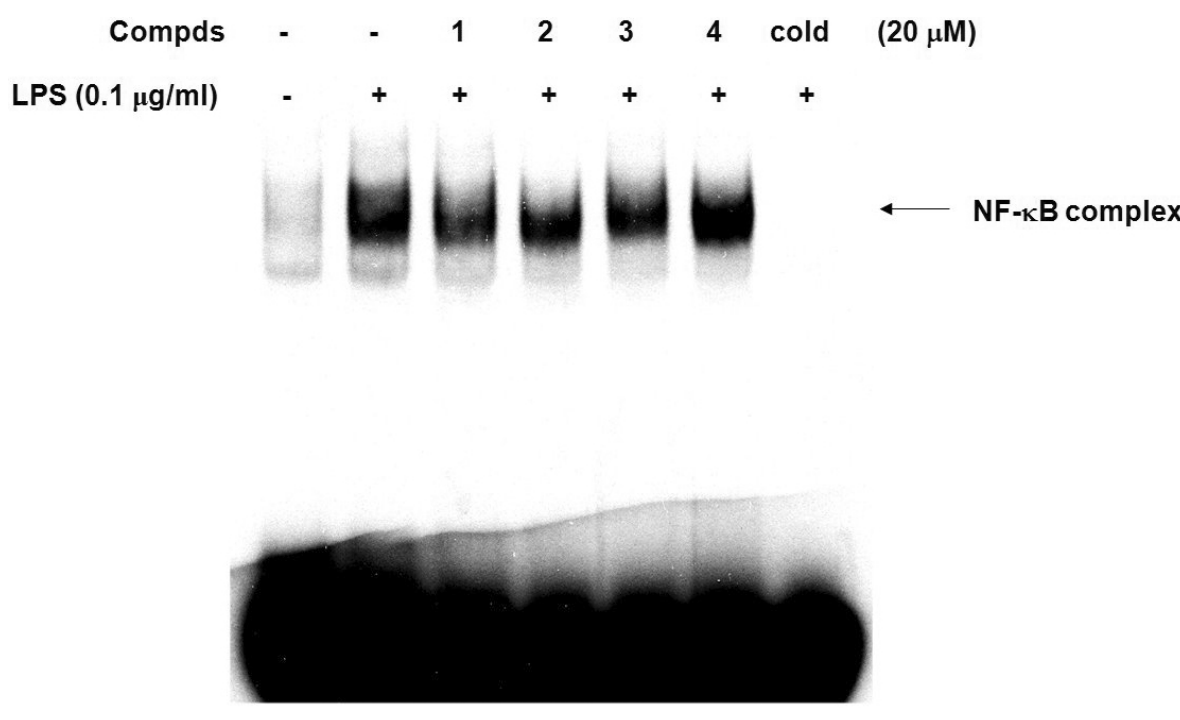

Fig. 6. Effect of compounds 1-4 on the DNA-binding ability of NF- $\mathrm{BB}$ in LPS-activated BV-2 cells. BV-2 cells were incubated in the presence of LPS $(0.1 \mu \mathrm{g} / \mathrm{ml})$ for $15 \mathrm{~min}$. Compounds $(20$ $\mu \mathrm{M})$ were pretreated $1 \mathrm{~h}$ before LPS. Nuclear extracts were prepared and analyzed for the presence of NF-кB binding activity in electrophoretic mobility gel shift assay. Images are the representative of three independent experiments that show similar results.

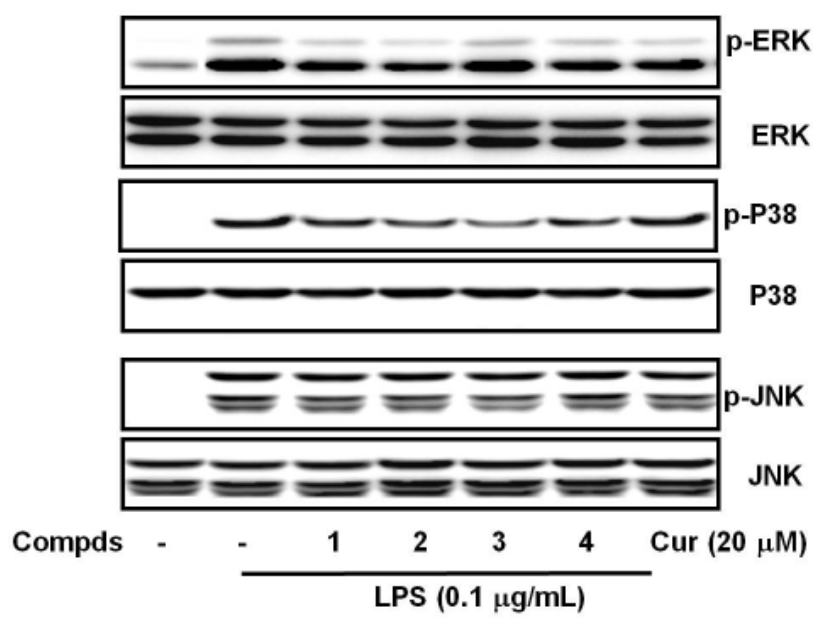

Fig. 7. Effect of compounds 1-4 on the LPS-induced activation of MAPKs in BV-2 cells. Cells were pre-treated with compounds for 30 min prior to stimulation of LPS. After treatment with LPS $(0.1 \mu \mathrm{g} / \mathrm{ml})$ for an additional $15 \mathrm{~min}$, proteins were extracted and analyzed the levels of phosphorylated ERK1/2, p38 and JNK by Western blot. Images are the representative of three independent experiments that show similar results.

binding activity (Fig. 6) in EMSA analysis.

In previous studies, it has been demonstrated that the MAP kinase (MAPK) pathways are involved in LPS-induced production of COX-2 and iNOS via control of NF- $\mathrm{kB}$ activation in microglial cells (Moon et al., 2007; Jung et al., 2009). To investigate the molecular mechanisms involved in the inhibition of NF-KB activation, we examined the effect of compounds on LPS-stimulated phosphorylation of ERK1/2, p38, and JNK in microglial cells. Cells were pretreated with compounds for 30 min and then stimulated with LPS $(0.1 \mu \mathrm{g} / \mathrm{ml})$ for $30 \mathrm{~min}$. The phosphorylation of ERK1/2, p38 and JNK was increased by LPS stimulation. Compounds 1-4 reduced LPS-induced phosphorylation of $\mathrm{p} 38$ and ERK1/2, whereas phosphorylation of JNK was not affected (Fig. 7). Non-phosphorylated ERK1/2, p38 and JNK were not changed by the treatment of LPS and test compounds. These results indicate that the suppressed phosphorylation of $\mathrm{p} 38$ and ERK1/2 may contribute to the inhibitory effect of compounds on LPS-induced NF- $\kappa B$ activation and pro-inflammatory responses in microglial cells.

These activities could be extrapolated to the inhibition of other inflammatory mediators such as IL-1 $\beta$, IL- 6 and TNF- $\alpha$,

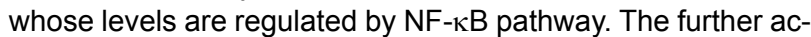
tivity mechanism and the permeability of blood-brain barrier of the active compounds should be investigated for the successful drug development for CNS. Microglia are resident macrophage-like cells that play a role in host defense and tissue repair in the CNS (Perry and Gordon, 1988). However, activated microglia play a pivotal role in the amplication of inflammation and the mediation of cellular degeneration (Gonzalez-Scarano and Baltuch, 1999). PGE $_{2}$ released from activated microglia participates in the process of neuronal cell death through DNA damage and mitochondrial disruption. COX-2 is expressed in activated microglia which appear to be an important source of PGs during inflammation conditions (Bauer et al., 1997). Therefore, inhibition of these mediators may have beneficial effects in the treatment of neuronal inflammatory reaction and diseases.

In summary, four flavonoids, 3,4'-dimethylquercetin (1), 3,7-dimethylquercetin (2), 3-methylquercetin (3) and 3,7,4'-trimethylquercetin (4) were isolated from Siegesbeckia glabrescens as inhibitors of $\mathrm{PGE}_{2}$ production in LPS-activated microglia. They exerted their activity through the inhibition of NF-KB activation and subsequent suppression of protein and mRNA expression of COX-2. These results imply that Siegesbeckia glabrescens may be beneficial in the treatment of neuro-inflammatory diseases through the inhibition of PGs.

\section{ACKNOWLEDGMENTS}

This work was supported by a Sookmyung Women's University research grants in 2009 . 


\section{REFERENCES}

Allen, R. G. and Tresini, M. (2000) Oxidative stress and gene regulation. Free Radic. Biol. Med. 28, 463-499.

Barberá, J., Marco, J. A., Sanz, J. F. and Sánchez-Parareda, J. (1986) 3-Methoxyflavones and coumarins from Artemisia incanescens. Phytochem. 25, 2357-2360.

Bauer, M. K., Lieb, K., Schulze-Osthoff, K., Berger, M., GebickeHaerter, P. J., Bauer, J. and Fiebich, B. L. (1997) Expression and regulation of cyclooxygenase-2 in rat microglia. Eur. J. Biochem. 243, 726-731.

Block, M. L., Zecca, L. and Hong, J. S. (2007) Microglia-mediated neurotoxicity: uncovering the molecular mechanisms. Nat. Rev. Neurosci. 8, 57-69.

Brock, T. G., McNish, R. W. and Peters-Golden, M. (1999) Arachidonic acid is preferentially metabolized by cyclooxygenase- 2 to prostacyclin and prostaglandin E2. J. Biol. Chem. 274, 11660-11666.

Chen, Y. C., Shen, S. C., Lee, W. R., Hou, W. C., Yang, L. L. and Lee, T. J. (2001) Inhibition of nitric oxide synthase inhibitors and lipopolysaccharide induced inducible NOS and cyclooxygenase-2 gene expressions by rutin, quercetin, and quercetin pentaacetate in RAW 264.7 macrophages. J. Cell. Biochem. 82, 537-548.

Gonzalez-Scarano, F. and Baltuch, G. (1999) Microglia as mediators of inflammatory and degenerative diseases. Annu. Rev. Neurosci. 22, 219-240.

Harris, S. G., Padilla, J., Koumas, L., Ray, D. and Phipps, R. P. (2002) Prostaglandins as modulators of immunity. Trends Immunol. 23 144-150.

Jun, S. Y., Choi, Y. H. and Shin, H. M. (2006) Siegesbeckia glabrescens induces apoptosis with different pathways in human MCF-7 and MDA-MB-231 breast carcinoma cells. Oncol. Rep. 15,14611467.

Jung, W. K., Ahn, Y. W., Lee, S. H., Choi, Y. H., Kim, S. K., Yea, S. S. Choi, I., Park, S. G., Seo, S. K., Lee, S. W. and Choi, I. W. (2009) Ecklonia cava ethanolic extracts inhibit lipopolysaccharide-induced cyclooxygenase-2 and inducible nitric oxide synthase expression in BV2 microglia via the MAP kinase and NF-kappaB pathways. Food Chem. Toxicol. 47, 410-417.

Kim, H. M., Lee, J. H., Won, J. H., Park, E. J., Chae, H. J., Kim, H. R. Kim, C. H. and Baek, S. H. (2001) Inhibitory effect on immunoglobulin E production in vivo and in vitro by Siegesbeckia glabrescens. Phytother. Res. 15, 572-576.

Kim, J. Y., Lim, H. J. and Ryu, J. H. (2008) In vitro anti-inflammatory activity of 3-O-methyl-flavones isolated from Siegesbeckia glabrescens. Bioorg. Med. Chem. Lett. 18, 1511-1514.

Kim, Y. M., Lee, B. S., Yi, K. Y. and Paik, S. G. (1997) Upstream NFkappaB site is required for the maximal expression of mouse inducible nitric oxide synthase gene in interferon-gamma plus lipopolysaccharide-induced RAW 264.7 macrophages. Biochem. Biophys. Res. Commun. 236, 655-660.

Klein, J. A. and Ackerman, S. L. (2003) Oxidative stress, cell cycle, and neurodegeneration. J. Clin. Invest. 111, 785-793.

Kyrkanides, S., Moore, A. H., Olschowka, J. A., Daeschner, J. C., Williams, J. P., Hansen, J. T. and Kerry O'Banion, M. (2002) Cyclooxygenase-2 modulates brain inflammation-related gene expression in central nervous system radiation injury. Brain Res. Mol. Brain Res. 104, 159-169.

Lee, J., Hur, J., Lee, P., Kim, J. Y., Cho, N., Kim, S. Y., Kim, H., Lee, M. S. and Suk, K. (2001) Dual role of inflammatory stimuli in activation-induced cell death of mouse microglial cells. Initiation of two separate apoptotic pathways via induction of interferon regulatory factor-1 and caspase-11. J. Biol. Chem. 276, 32956-32965.

Lee, M. H., Kim, J. Y. and Ryu, J. H. (2005) Prenylflavones from Psoralea corylifolia inhibit nitric oxide synthase expression through the inhibition of I-kappaB-alpha degradation in activated microglial cells. Biol. Pharm. Bull. 28, 2253-2257.

Lehnardt, S., Massillon, L., Follett, P., Jensen, F. E., Ratan, R., Rosenberg, P. A., Volpe, J. J. and Vartanian, T. (2003) Activation of innate immunity in the CNS triggers neurodegeneration through a Toll-like receptor 4-dependent pathway. Proc. Natl. Acad. Sci. USA. 100, 8514-8519.

McGeer, P. L. and McGeer, E. G. (1995) The inflammatory response system of brain: implications for therapy of Alzheimer and other neurodegenerative diseases. Brain Res. Brain Res. Rev. 21, 195218.

Minghetti, L. (2004) Cyclooxygenase-2 (COX-2) in inflammatory and degenerative brain diseases. J. Neuropathol. Exp. Neurol. 63, 901910.

Moon, D. O., Choi, Y. H., Kim, N. D., Park, Y. M. and Kim, G. Y. (2007) Anti-inflammatory effects of beta-lapachone in lipopolysaccharidestimulated BV2 microglia. Int. Immunopharmacol. 7, 506-514.

Peri, K. G., Hardy, P., Li, D. Y., Varma, D. R. and Chemtob, S. (1995) Prostaglandin $\mathrm{G} / \mathrm{H}$ synthase-2 is a major contributor of brain prostaglandins in the newborn. J. Biol. Chem. 270, 24615-24620.

Perry, V. H. and Gordon, S. (1988) Macrophages and microglia in the nervous system. Trends Neurosci. 11, 273-277.

Pradelles, P., Grassi, J. and Maclouf, J. (1985) Enzyme immunoassays of eicosanoids using acetylcholine esterase as label: an alternative to radioimmunoassay. Anal. Chem. 57, 1170-1173.

Ramachandran Nair, A. G., Ramesh, P., Sankara Subramanian, S. and Joshi, B. S. (1978) Rare methylated flavonols from Angelonia grandiflora. Phytochem. 17, 591-592.

Ryu, J. H., Son, H. J., Lee, S. H. and Sohn, D. H. (2002) Two neolignans from Perilla frutescens and their inhibition of nitric oxide synthase and tumor necrosis factor-alpha expression in murine macrophage cell line RAW 264.7. Bioorg. Med. Chem. Lett. 12, 649-651.

Wang, Y., Hamburger, M., Gueho, J. and Hostettmann, K. (1989) Antimicrobial flavonoids from Psiadia trinervia and their methylated and acetylated derivatives. Phytochem. 28, 2323-2327.

Ye, J., Ghosh, P., Cippitelli, M., Subleski, J., Hardy, K. J., Ortaldo, J. R. and Young, H. A. (1994) Characterization of a silencer regulatory element in the human interferon-gamma promoter. J. Biol. Chem. 269, 25728-25734.

Yoon, J. H., Lim, H. J., Lee, H. J., Kim, H. D., Jeon, R. and Ryu, J. H. (2008) Inhibition of lipopolysaccharide-induced inducible nitric oxide synthase and cyclooxygenase-2 expression by xanthanolides isolated from Xanthium strumarium. Bioorg. Med. Chem. Lett. 18, 2179-2182.

Zielasek, J. and Hartung, H. P. (1996) Molecular mechanisms of microglial activation. Adv. Neuroimmunol. 6, 191-222. 